\title{
Pengaruh Pemberian Terapi Guided Imagery terhadap Perubahan Intensitas Nyeri Ibu Bersalin Post Sectio Caesarea di Rumah Sakit Bersalin Di Kota Padang
}

\author{
Silfina Indriani ${ }^{1 *}$, Ika Yulia Darma ${ }^{2}$ \\ ${ }^{1}$ Stikes Alifah, Jln. Khatib Sulaiman Padang \\ ${ }^{2}$ Stikes Syedza Saintika, Jln. Prof Dr Hamka No 228 Padang \\ *Correspondence email: ika_yd1102@yahoo.com
}

\begin{abstract}
Abstrak. Trend persalinan secara sectio caesarea (SC) di Indonesia meningkat sebesar $10 \%$ dari $7 \%$ pada SDKI 2007 menjadi 17\% pada SDKI 2017. Nyeri merupakan ketidaknyaman yang sering alami oleh ibu bersalin post sectio caesarea. Penatalaksanaan nyeri secara komplementer dapat dilakukan dengan terapi guided imagery. Tujuan penelitian ini untuk mengetahui pengaruh pemberian terapi guided imagery terhadap perubahan intensitas nyeri ibu bersalin post sectio caesarea di rumah sakit bersalin di kota Padang tahun 2021. Jenis penelitian quasy eksperiment dengan rancangan one group pretest posttest. Populasi penelitian ibu bersalin post sectio caesarea dengan jumlah sampel sebanyak 30 orang, pengambilan sampel menggunakan teknik purposive sampling. Data dianalisa secara univariat dan bivariat menggunakan uji statistik paired sample $t$-test. Hasil penelitian didapatkan intensitas nyeri ibu sebelum intervensi rata-rata 6,90 dan setelah pemberian terapi guided imagery intensitas nyeri rata-rata 3,70 dengan selisih rerata sebesar 3,20. Hasil uji statistik menunjukan terdapat pengaruh pemberian terapi guided imagery terhadap perubahan intensitas nyeri ibu bersalin post sectio caesarea dengan nilai $p$ value sebesar 0,000 ( $\mathrm{p}$ value $<0,05$ ). Terdapat pengaruh yang signifikan antara intensitas nyeri ibu bersalin post sectio caesarea sebelum dan sesudah diberikan terapi guided imagery. Diharapkan terapi ini dapat diimplementasikan dalam penatalaksanan nyeri yang dialami oleh ibu pasca salin sectio caesarea.
\end{abstract}

Kata kunci: Guided imagery ; nyeri ; post sectio caesarea

Abstract. The trend of delivery by caesarean sectio (SC) in Indonesia increased by 10\% from 7\% in the 2007 IDHS to $17 \%$ in the 2017 IDHS. Pain is an inconvenience that is often experienced by women giving birth after caesarean sectio. Complementary pain management can be done with guided imagery therapy. The purpose of this study was to determine the effect of giving guided imagery therapy to changes in the intensity of pain in post-sectio caesarean delivery mothers at a maternity hospital in the city of Padang in 2021.This type of research is quasi-experimental with a one group pretest posttest design. The research population was post-sectio caesarean delivery mothers with a total sample of 30 people, sampling using purposive sampling technique. Data were analyzed univariately and bivariately using paired sample t-test. The results showed that the average maternal pain intensity before intervention was 6.90 and after guided imagery therapy the average pain intensity was 3.70 with a mean difference of 3.20. The results of statistical tests showed that there was an effect of giving guided imagery therapy to changes in the intensity of pain in postpartum mothers with caesarean sectio with a $p$ value of 0.000 ( $p$ value <0.05). There is a significant effect between the pain intensity of post-cesarean delivery mothers before and after being given guided imagery therapy. It is hoped that this therapy can be implemented in the management of pain experienced by mothers after caesarean sectio.

Keywords: Guided Imagery; Pain; Post Sectio Caesarean

\section{PENDAHULUAN}

Persalinan secara sectio caesarea adalah proses persalinan yang dilakukan dengan cara pembedahan pada dinding abdomen dan dinding uterus (Cunigham et al., 2013). Persalinan sectio caesarea ini dapat mengurangi kematian ibu dan bayi serta mengurangi resiko komplikasi pasca salin. Data Word Health Organitation (WHO) pada tahun 2015 selama hampir 30 tahun tingkat persalinan dengan sectio caesarea menjadi $10 \%$ sampai $15 \%$. Trend persalinan secara sectio caesarea (SC) di Indonesia meningkat sebesar $10 \%$ dari $7 \%$ pada SDKI 2007 menjadi 17\% pada SDKI 2017 (Kemenkes RI, 2017) Rata- rata pasien post sectio caesarea mengalami nyeri, tampak menangis, gelisah dan kadang mengalami stres
Rasa nyeri merupakan salah satu ketidaknyamanan yang disebabkan oleh peregangan abdomen dan luka insisi yang sering dialami pada ibu post sectio caesarea (SC). Persalinan SC memberikan rasa nyeri lebih tinggi dibandingkan dengan persalinan pevaginam. Nyeri adalah suatu tanggapan subjektif kepada stress fisik dan psikologi yang disebabkan oleh stimulus tertentu. Nyeri yang dirasakan oleh ibu post SC bervariasi mulai dari tingkat ringan sampai ke tingkat berat sekali (Kosasih, 2015). Rasa nyeri post SC dirasakan selama beberapa hari.

Rasa nyeri pada ibu post SC dapat diatasi dengan penatalaksanaan manajemen nyeri. Hal ini bertujuan untuk mengurangi atau meringankan rasa nyeri sampai tingkat kenyamanan yang dirasakan oleh ibu post SC. 
Silfina Indriani dan Ika Yulia Darma, Pengaruh Pemberian Terapi Guided Imagery terhadap Perubahan Intensitas Nyeri Ibu Bersalin Post Sectio Caesarea di Rumah Sakit Bersalin Di Kota Padang

Penatalaksanaan nyeri dapat dilakukan secara farmakologi dan non farmakologi (komplementer). Secara farmakologi dapat dilakukan dengan pemberian obat-obatan analgetik, sedangkan cara non farmakologis dapat dilakukan dengan cara akupuntur, masase, relaksasi benson, dan guided imagery

Guided imagery adalah teknik yang mempelajari kekuatan pikiran saat sadar atau tidak sadar untuk menciptakan bayangan / imajinasi yang menghadirkan ketenangan dan kesunyian. Efek guided imagery menyebabkan pasien mengalihkan perhatiannya pada rasa sakit ke hal-hal yang membuatnya senang dan bahagia sehingga meluapkan rasa sakit yang dialaminya. Hal ini yang menyebabkan intensitas nyeri yang diurasakan pasien pasca operasi sectio caesarea menurun setalah dilakukannya teknik guided imagery.

Tujuan penelitian ini yaitu untuk mengetahui pengaruh pemberian teknik guided imagery terhadap perubahan intensitas nyeri ibu bersalin post sectio caesarea di rumah sakit bersalin di kota padang.

\section{METODE}

Jenis penelitian ini adalah quasy eksperiment. Pendekatan penelitian cross sectioal dengan rancangan one group pretest and postest (Siyoto \& Sodik, 2015). Penelitian dilaksanakan pada bulan Mei - Desember 2020 di rumah sakit bersalin di Kota Padang. Populasi penelitian ini adalah semua ibu bersalin post SC dari tanggal 20 Juni sampai 08 September 2021 dengan jumlah pasien 30 orang. Teknik sampel dengan purposive sampling.

Kriteria inklusi penelitian adalah 1) ibu bersalin post SC 1 x 24 jam, 2) bersedia menjadi responden, 3) pasien mengeluh nyeri. Kriteria ekslusi yaitu pasien tidak kooperatif dan tidak bersedia menjadi responden.Teknik pengumpulan data menggunakan lembar observasi dan SOP teknik guided imagery.

Analisa data dilakuakan secara univariat dan bivariat. Analisa univariat meliputi karakteristik responden berdasarkan distribuasi frekuensi umur dan pendidikan, mean dan standar deviasi sebelum dan sesudah diberikan intervensi guided imagery. Analisa bivariat menggunakan uji paired sampel t- test.

\section{HASIL DAN PEMBAHASAN Analisa Univariat}

Tabel 1. Distribusi Frekunsi Karakteristik Responden Berdasarkan Umur dan Pendidikan

\begin{tabular}{lcc}
\hline \multicolumn{1}{c}{ Variabel } & f & $\%$ \\
\hline Umur & & \\
$<21$ tahun & 1 & 3,3 \\
$21-35$ tahun & 4 & 80,0 \\
$>$ 35 tahun & 24 & 16,7
\end{tabular}

\begin{tabular}{lcc} 
Pendidikan & & \\
SMP & 5 & 16,7 \\
SMA & 18 & 60,0 \\
Perguruan Tinggi & 7 & 23,3 \\
\hline
\end{tabular}

Berdasarkan tabel 1 menunjukan bahwa sebagian besar responden $(80,0 \%)$ berumur $21-35$ tahun dan sebagian besar responden $(60 \%)$ berpendidikan SMA.

Tabel 2. Rerata intensitas nyeri sebelum dan sesudah diberikan intera

\begin{tabular}{lccc}
\hline Intensitas Nyeri & n & Mean & Min-Max \\
\hline Sebelum & 30 & 6,90 & $5,00-9,00$ \\
Setelah & 30 & 3,70 & $1,00-6,00$ \\
\hline
\end{tabular}

Berdasarkan tabel 2 menunjukan bahwa ibu bersalin post SC sebelum pemberian terapi guided imagery memiliki intensitas nyeri rata-rata 6,90. Setelah pemberian intervensi terapi guided imagery intensitas nyeri rata-rata 3,70 .

\section{Analisa Bivariat}

Tabel 3. Pengaruh Terapi Guided Imagery Terhadap Perubahan Intensitas Nyeri Ibu Bersalin Post Sectio Caesarea di Rumah Sakit Bersalin di Kota Padang

\begin{tabular}{lcrcc}
\hline Intensitas Nyeri & N & Mean & SD & p value \\
\hline Sebelum & 30 & 6,90 & 1,028 & 0,000 \\
Setelah & 30 & 3,70 & 1,290 & \\
Selisih & 30 & 3,20 & 1,399 & \\
\hline
\end{tabular}

Analisa bivariat dilakukan untuk mengetahui pengaruh variabel bebas dengan variabel terikat sebelum dan sesuadah diberikan intervensi. Analisa ini melihat pengaruh sebelum dan sesudah pemberian terapi guided imagery pada ibu bersalin post SC.

Berdasarkan tabel 3 menunjukan bahwa ibu bersalin post SC sebelum pemberian terapi guided imagery memiliki intensitas nyeri rata-rata 6,90 dengan standar deviasi 1,028. Setelah pemberian intervensi terapi guided imagery intensitas nyeri rata-rata 3,70 dengan standar deviasi 1,290. Selisih intensitas nyeri ibu post SC sebelum dan sesudah intervensi terapi guided imagery rata-rata 3,20 dengan standar deviasi 1,399. Nilai $\mathrm{p}$ value menunjukan 0,000 yang bearti ada pengaruh guided imageri terhadap perubahan intensitas nyeri ibu bersalin post SC.

\section{Pembahasan}

Hasil penelitian menunjukan terjadinya penurunan rata-rata intensitas nyeri sebelum $(6,90)$ dan sesudah $(3,70)$ diberikan terapi guided imagery pada ibu bersalin post SC dengan selisih rata-rata 3,20 dengan nilai $p$ value 0,000 .

Penelitian yang dilakukan oleh Erawati dkk di rumah sakit tingkat II Pelamonia Makasar tahun 2019 terapi guided imagery terbukti dapat menurunkan tingkat nyeri sebelum sasudah pemberian terapi guided imagery 
pada pasien post operasi caesarea (Erawati et al., 2019). Penelitian lain yang sejalan penelitian Muchsin dkk tahun 2020 menunjukan teknik relaksasi nafas dalam dan guided imagery dapat menurunkan nyeri pada pasien post section caesarea di RSU GMIM Pancaran Kasih Manado

Guided imagery adalah teknik relaksasi yang melibatkan visualisasi tempat dengan situasi tenang dan damai. Teknik ini dapat mengatasi gejala stres dan kecemasan, serta membantu agar tubuh dan pikiran menjadi lebih rileks. Guided imagery bisa membantu mengurangi rasa nyeri yang tengah dirasakan oleh pasien dengan mengelola stres yang timbulkan oleh rasa nyeri tersebut. Saat stress dapat dikelola dengan baik maka nyeri yang dirasakan akan berkurang dengan sendirinya.

Salah satu penerapan terapi guided imagery ini dapat di aplikasikan kepada ibu bersalin post sectio caesarea. Rasa nyeri post SC yang dialami oleh ibu bersalin akibat luka insisi pada dinding abdomen dan dinding rahim dapat menyebabkan terganggunya emosinal ibu. Rasa nyeri yang dialami membuat ibu mudah stres dan cemas karena ketidanyamanan yang dirasakan.

Guided imagery dilakukan dengan mengajak pasien untuk melakukan relaksasi nafas dalam yang santai, dan membayangkan dirinya sedang berada di tempat yang santai, sejuk yang membuat pasien merasa nyaman berada disana, membawa dalam keadaan rileks dan hanyut dalam imajinasinya (Prabu \& Subhash, 2015)

Cara kerja Guided Imagery kepada tubuh dengan mempengaruhi sistem saraf autonom. Responden dianjurkan untuk nafas dalam, secara perlahan tubuh responden akan merasakan rileks. Perasaan rileks akan diteruskan ke hipotalamus untuk menghasilkan Corticotropin Releasing Factor (CRF). Selanjutnya $C R F$ merangsang kelenjar pituitary untuk meningkatkan produksi Proopioidmelanocortin(POMC) yang menyebabkan meningkatnya produksi enkephalin oleh medulla adrenal. Kelenjar pituitary juga menghasilkan endorphin neurotransmiter yang dipercaya mempengaruhi suasana hati menjadi rileks (Guyton \& Hall, 2007). Rasa rileks yang diperoleh oleh pasien setelah mendapatkan terapi membuat pasien dapat mengelola rasa nyeri yang dirasakannya.

\section{SIMPULAN}

Berdasarkan penelitian Pemberian terapi Guided Imagery dapat menurunkan intensitas nyeri ibu bersalin post sectio caesarea. Hasil uji statistik menunjukan adanya pengaruh pemberian terapi guided imagery terhadap perubahan intensitas nyeri ibu bersalin post section caesarea di rumah sakit bersalin di kota Padang tahun 2021.
DAFTAR PUSTAKA

Cunigham, L., Houth, B., \& Rouse, S. (2013). Obstetri Williams. EGC.

Erawati, Kasim, J., \& Askar, E. (2019). Pengaruh Guided Imagery Terhadap Tingkat Nyeri Pada Pasien Post Operasi Sectio Caesarea di Rumah Sakit TK II Pelamonia Makasar. Jurnal Ilmiah Kesehatan Diagnosis, 14(3).

Guyton, \& Hall. (2007). Buku Ajar Fisiologi Kedokteran (11th ed.). EGC.

Kemenkes RI. (2017). Survey Demografi Kesehatan Indonesia.

Kosasih, C. (2015). Konsep dan Aplikasi Relaksasi dalam Keperawatan Maternitas. PT Refika Aditama.

Prabu, P., \& Subhash, J. (2015). Guided Imagery Theraphy. IOSR Journal of Nursing Health Science, 4(5), 56-58.

Siyoto, \& Sodik. (2015). Dasar Metodologi Penelitian. Literasi Media Publishing. 